\title{
PENGARUH TECHNOLOGY ACCEPTANCE MODEL (TAM) PADA KEMAMPUAN KEYAKINAN DIRI ATAS KOMPUTER PENGGUNA SISTEM INFORMASI AKUNTANSI DI PT BANK RAKYAT INDONESIA, TBK. CABANG GIANYAR
}

\author{
Putu Yudha Asteria Putri ${ }^{1^{*}}$, A.A. Gde Agung Parameswara ${ }^{2}$ \\ Email: ydhasteria.putri@gmail.com
}

\begin{abstract}
This study aims to determine the extent to which the Technology Acceptance Model (TAM) is used in the implementation of activities at PT Bank Rakyat Indonesia, Tbk. and its effect on self confidence in computers. Moreover PT. Bank Rakyat Indonesia (BRI), Tbk. is one of the state-owned banking companies, the assessment of employee satisfaction should be the focus of attention, both from management and the public who have bought shares or become a customer at the bank. This study took 124 research samples, namely the purposive sampling method with the criteria for employees who became the study sample were employees using the Accounting Information System. Multiple linear regression techniques are used in this study and get the results of the Technology Acceptance Model which consists of perceived easy of use, perceived usefulness and actual usage have a positive effect on self-confidence of the computer users of Accounting Information Systems at PT Bank Rakyat Indonesia, Tbk. Gianyar.
\end{abstract}

Keywords : Technology Acceptance Model; Confidence in Computers; Accounting Information Systems

\begin{abstract}
ABSTRAK
Penelitian ini bertujuan untuk mengetahui sejauh mana Technology Acceptance Model (TAM) digunakan dalam pelaksanaan kegiatan di PT Bank Rakyat Indonesia, Tbk. serta pengaruhnya pada keyakinan diri atas komputer. Terlebih PT. Bank Rakyat Indonesia (BRI), Tbk. merupakan salah satu perusahaan perbankan milik negara, penilaian terhadap kepuasan karyawan seharusnya menjadi fokus perhatian, baik dari pihak manajemen maupun masyarakat yang sudah membeli saham atau menjadi nasabah di bank tersebut. Penelitian ini mengambil sebanyak 124 sampel penelitian yaitu dengan metode purposive sampling dengan kriteria karyawan yang menjadi sampel penelitian adalah karyawan yang menggunakan Sistem Informasi Akuntansi. Teknik regresi linier berganda digunakan dalam penelitian ini dan mendapatkan hasil Technology Acceptance Model yang terdiri dari perceived easy of use, perceived usefulness dan actual usage berpengaruh positif pada keyakinan diri atas komputer pengguna Sistem Informasi Akuntansi di PT Bank Rakyat Indonesia, Tbk. cabang Gianyar.

Kata Kunci : Technology Acceptance Model; Keyakinan Diri Atas Kompter; Sistem Informasi Akuntansi
\end{abstract}

\footnotetext{
*Corresponding author. Email: ydhasteria.putri@gmail.com
} 


\section{PENDAHULUAN}

Sistem Informasi (SI) mempunyai peranan penting dalam akuntansi. Sadha (2012) menyebutkan bahwa akuntansi sebagai SI mempunyai tujuan sebagai penyedia informasi bagi pengambil keputusan. Setiap perusahaan berhadapan dengan masalah pengambilan keputusan. Informasi yang memadai (akurat, tepat waktu, dan tepat nilainya) merupakan solusinya yang umumnya dihasilkan oleh SI berbasis computer dan disebut dengan Sistem Informasi Akuntansi (SIA). Model penerimaan teknologi (Technology Acceptance Model/ TAM) pertama kali dikembangkan oleh Davis, 1986 merupakan model Sisten Informasi yang dikembangkan untuk memprediksi pengadopsian dan penggunaan Sistem Informasi. TAM merupakan aplikasi dari teori tindakan beralasan /Theory of Reasoned Action (TRA) yg diadopsi secara luas. TAM menambahkan dua konstruk utama ke dalam model TRA, yaitu: kegunaan dan kemudahan penggunaan disamping kontstruk lainnya, yaitu minat untuk menggunakan dan penggunaan (Davis,1989). Tujuan model ini adalah untuk dapat menjelaskan faktor-faktor utama dari perilaku pengguna teknologi informasi terhadap penerimaan dan penggunaan teknologi informasi itu sendiri.

Davis et. al. (1989) melakukan penelitian tentang penerimaan personal komputer yang salah satu temuannya menunjukkan bahwa persepsi kegunaan dan persepsi kemudahan penggunaan berpengaruh langsung terhadap penggunaan sistem dan persepsi kegunaan berpengaruh langsung terhadap persepsi kemudahan penggunaan. Lain halnya penelitian Hasan (2007) dan Sadha (2012) menguji pengaruh variabel keyakinansendiri dalam membangun variabel persepsi kemudahan penggunaan, persepsi kegunaan, minat untuk menggunakan, dan penggunaan TI. Temuannya menunjukkan bahwa keyakinan-diri atas komputer berpengaruh terhadap persepsi kemudahan penggunaan, persepsi kegunaan dan perceived system complexity; persepsi kemudahan penggunaan berpengaruh terhadap persepsi kegunaan, sikap dan minat untuk menggunakan; serta persepsi kegunaan berpengaruh terhadap sikap, dan minat untuk menggunakan komputer.

Bagi PT. Bank Rakyat Indonesia (BRI), Tbk. sebagai salah satu perusahaan perbankan yang merupakan milik negara, penilaian terhadap kepuasan karyawan seharusnya menjadi fokus perhatian, baik dari pihak manajemen maupun masyarakat yang sudah membeli saham atau menjadi nasabah di bank tersebut. Salah satu Cabang PT Bank Rakyat Indonesia, Tbk. yang mempunyai kinerja yang baik adalah Bank Rakyat Indonesia Cabang Gianyar. BRI Cabang Gianyar memiliki 11 kantor yang menyebar di seluruh wilayah Kabupaten Gianyar, terdiri dari 8 buah kantor unit, 1 kantor cabang, 1 kantor cabang pembantu dan 1 Rumah Kreatif BRI (RKB Kabupaten Gianyar). BRI cabang Gianyar mempunyai prestasi kerja yang baik, salah satunya mendapatkan predikat kinerja terbaik se - Kantor Wilayah BRI Bali dari tahun ke tahun, selain itu BRI Cabang Gianyar juga merupakan satu-satunya penggerak ekonomi UMKM di daerah Bali - NTB. Namun sangat disayangkan pada kenyataannya di PT Bank Rakyat Indonesia khususnya di cabang Gianyar 
masih terdapat hal-hal yang membuat karyawan tidak merasa puas dalam menjalankan aktifitasnya. Karyawan sering bekerja diatas jam operasional akibat masih kurang baiknya sistem IT di PT Bank Rakyat Indonesia, Tbk. dapat dilihat dari sering lambatnya program yang dijalankan sehingga teller tidak dapat dengan tepat waktu untuk menyelesaikan balancesheet harian, lambatnya sistem menyebabkan terlambatnya pencairan kredit terhadap nasabah, eror sistem yang mengakibatkan nasabah tidak dapat menarik dana, dan kendala lain yang terkait dengan pelayanan terhadap nasabah, dimana nasabah merupakan harta bagi sebuah lembaga perbankan. Dilihat dari visi PT. Bank Rakyat Indonesia yang berbunyi "Menjadi bank komersial terkemuka yang selalu mengutamakan kepuasan nasabah.", semakin menunjukkan bahwa pertumbuhan bank yang sehat sudah menjadi hal yang selalu diutamakan untuk kepercayaan nasabah. Pertumbuhan yang sehat bisa dilihat dari apakah pimpinan dan seluruh karyawan khususnya yang menggunakan sistem kas sudah merasa puas saat bekerja dalam menghasilkan laporan keuangan yang akan disajikan kepada penggunanya.

\section{KAJIAN LITERATUR}

\section{Technology Acceptance Model (TAM)}

TAM mendasarkan diri pada Theory of Reasoned Action (TRA) yang dikemukakan Ajzen dan Fisbein (1980). TRA menjelaskan adanya reaksi dan persepsi pengguna Teknologi Informasi (TI) yang pada akhirnya akan mempengaruhi sikapnya dalam penerimaan terhadap teknologi tersebut. Tujuan utama TAM adalah memberikan penjelasan tentang penentuan penerimaan komputer secara umum, memberikan penjelasan tentang perilaku atau sikap pengguna dalam suatu populasi (Davis et.al., 1989). TAM menyatakan bahwa behavioral intension to use ditentukan oleh dua keyakinan yaitu: pertama, perceived usefulness yang didefinisikan sebagai sejauh mana seseorang yakin bahwa menggunakan sistem akan meningkatkan kinerjanya. Kedua, perceived ease of use yang didefinisikan sebagai sejauh mana seseorang yakin bahwa penggunaan sistem adalah mudah. TAM juga menyatakan bahwa dampak variabel-variabel eksternal seperti (karakteristik sistem, proses pengembangan dan pelatihan) terhadap intension to use adalah dimediasi oleh perceived of usefulness dan perceived ease of use. Konsep TAM juga menyatakan bahwa perceived usefulness dipengaruhi oleh perceived ease of used. Venkatesh dan Davis (2000) menyatakan bahwa TAM merupakan sebuah konsep yang dianggap paling baik dalam Supporting Theory. menjelaskan perilaku user terhadap sistem teknologi informasi baru. TAM merupakan model yang dianggap paling tepat dalam menjelaskan bagaimana user menerima sebuah sistem. Lee, et. all. (2005) mengemukakan bahwa penelitian terhadap implementasi penggunaan teknologi harus didasarkan pada motivasi ekstrinsik intrinsic dari karyawan, yang pada nantinya dapat menjadi sarana untuk informasi, menyusun strategi yang efisien dalam mempromosikan e-learning di tempat kerja. Ada beberapa perbedaan antara motivasi intrinsik dan ekstrinsik. Lee, et. all (2005) menganggap motivasi intrinsik sebagai faktor yang memengaruhi perilaku pengguna untuk kepentingannya 
sendiri seperti pekerjaan yang menarik dan menyenangkan. Mereka juga menggambarkan motivasi ekstrinsik sebagai faktor yang mempengaruhi perilaku seseorang seperti keinginan untuk mendapat penghargaan atau pengakuan untuk mematuhi perintah.

\section{Pengertian Sistem Informasi Akuntansi}

Sebelum membahas lebih jauh bagaimana suatu sistem informasi terpenting dalam menyajikan informasi yang akurat dan relevan, berikut ini akan diuraikan secara terperinci mengenai sistem informasi akuntansi tersebut.

Pengertian Sistem Informasi Akuntansi (SIA) adalah suatu komponen organisasi yang mengumpulkan, mengklasifikasikan, mengolah, menganalisa dan mengkomunikasikan informasi finansial dan pengambilan keputusan yang relevan bagi pihak luar perusahaan dan pihak dalam perusahaan. Menurut Moscove dan Simkin (2005) Sistem Informasi Akuntansi yaitu : "suatu komponen organisasi yang mengumpulkan, mengklasifikasikan, memproses, menganalisis, mengkomunikasikan informasi pengambilan keputusan dengan orientasi financial yang releven bagi pihak-pihak luar dan pihak-pihak dalam perusahaan (secara prinsip adalah manajemen)".

Berdasarkan definisi diatas, pengertian sistem informasi akuntansi dapat disimpulkan sebagai seperangkat manusia dan sumber modal dalam suatu organisasi yang berpengaruh dalam pengolahan data akuntansi untuk menghasilkan informasi akuntansi keuangan yang berguna bagi perusahaan sebagai dasar untuk pengambilan keputusan pihak manajemen dalam merencanakan dan mengendalikan perusahaan. Dalam menjalankan fungsinya sistem informasi akuntansi harus menpunyai tujuan-tujuan yang dapat menberikan pedoman kepada manajemen dalam melakukan tugasnya sehingga dapat menghasilkan informasi-informasi yang berguna terutama dalam menunjang perencanaan dan pengendalian.

\section{Computer Self Efficiacy}

Computer self efficacy oleh Indriantoro (2000:21) didefinisikan sebagai keahlian pemakai komputer (user) dalam hal aplikasi komputer, sistem operasi komputer, penanganan file dan perangkat keras, penyimpanan data dan penggunaan tombol keyboard. Pemakai komputer yang dimaksud adalah novice accountant assistant, yaitu mahasiswa yang berperan sebagai calon asisten akuntan. Keahlian menggunakan komputer sebagai judgement kapabilitas seseorang untuk menggunakan komputer/ sistem informasi/teknologi informasi. Ada tiga dimensi CSE, yaitu: 1) magnitude, 2) strength dan 3) generalibility. Dimensi magnitude mengacu pada tingkat kapabilitas yang diharapkan dalam penggunaan komputer. Individu yang mempunyai magnitude CSE yang tinggi diharapkan mampu menyelesaikan tugastugas komputasi yang lebih kompleks dibandingkan dengan individu yang mempunyai level magnitude CSE yang rendah karena kurangnya dukungan maupun bantuan.

\section{Kerangka Penelitian}




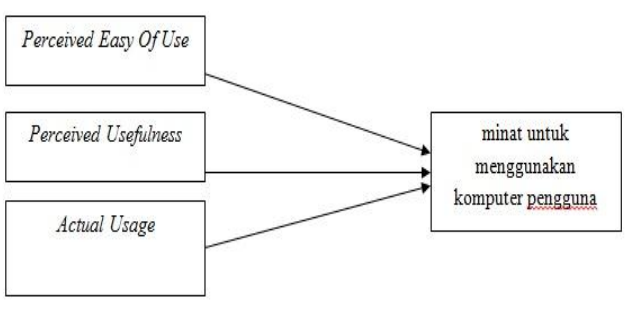

Gambar 1. Kerangka Penelitian

\section{METODE PENELITIAN}

Berdasarkan hipotesis penelitian, variabel-variabel yang digunakan dalam penelitian adalah perceived easy of use, perceived usefulness, actual usage dan minat untuk menggunakan komputer Pengumpulan data yang digunakan dalam penelitian ini meliputi: observasi, wawancara dan wawancara mendalam. Data yang telah terkumpul akan diolah dengan menggunakan teknik analisis statistik deskriptif. Dari jumlah popoulasi yaitu seluruh karyawan di PT Bank Rakyat Indonesia, Tbk. Cabang Gianyar, sampel dipilih berdasarkan metode non probability sampling yang menggunakan kriteria bahwa karyawan yang menjadi sampel merupakan karyawan yang menggunakan system IT dalam pekerjaannya dengan teknik pengambilan sampel jenuh.

\section{Teknik Analisis Data Statistik Deskriptif}

Penelitian ini menggunakan statistik deskriptif, jenis analisis statistik deskriptif yang digunakan dalam penelitian ini adalah analisis frekuensi. Menurut Wahyono (2002) analisis frekuensi merupakan analisis yang mencakup gambaran frekuensi data secara umum dan digunakan untuk meringkas data yang jumlahnya relatif besar. Hasil dari analisis deskriptif adalah frekuensi minimum, maximum, mean dan standar deviasi.

\section{Uji Kualitas Data}

Menurut Sujarweni (2016), uji validitas digunakan untuk mengetahui kelayakan setiap item pertanyaan dalam mendefinisikan suatu variabel. Uji validitas sebaiknya dilakukan pada setiap item pertanyaan dengan membandingkan hasil $\mathrm{r}$ hitung dengan $\mathrm{r}$ tabel, dimana $\mathrm{df}=$ n-2 dengan tingkat signifikansi $5 \%$. Jika $\mathrm{r}$ tabel < $\mathrm{r}$ hitung maka valid. Reliabilitas adalah ukuran suatu kestabilan dan konsistensi responden dalam menjawab hal yang berkaitan dengan setiap butir pertanyaan yang merupakan dimensi suatu variabel dan disusun dalam suatu kuesioner. Jika nilai Cronbach's Alpha > 0.70 maka suatu variabel dinyatakan reliabel (Ghozali, 2006).

\section{Analisis Regresi Linier Berganda}

Analisis regresi linear berganda menunjukkan arah hubungan antar variabel, apakah memiliki hubungan positif atau negatif. Variabel dependen yang digunakan dalam penelitian ini adalah perceived easy of use (persepsi kemudahan pengguna SIA), perceived usefulness (persepsi kegunaan SIA), actual usage (penggunaan SIA). Variabel independen yang digunakan dalam penelitian ini adalah computer self efficacy (keyakinan diri atas komputer). Persamaan analisis regresi linear berganda adalah sebagai berikut.

$\mathrm{Y}=\alpha+\beta 1 \mathrm{X} 1+\beta 2 \mathrm{bX} 2+\beta 3 \mathrm{X} 3+\varepsilon(1)$

Keterangan:

Y : computer self efficacy (keyakinan diri atas komputer)

$\alpha \quad$ : konstansta 
$\beta \quad$ : koefisien regresi

$\mathrm{X}_{1} \quad$ : perceived easy of use (persepsi

kemudahan pengguna SIA)

$\mathrm{X}_{2} \quad$ : perceived usefulness (persepsi

kegunaan SIA)

$\mathrm{X}_{3} \quad$ :actual usage (penggunaan SIA)

$\varepsilon \quad:$ error term

\section{HASIL DAN PEMBAHASAN}

Setelah semua uji asumsi klasik terpenuhi maka tahap selanjutnya adalah melakukan uji regresi linear berganda dengan model dasar sebagai berikut:

$\mathrm{Y}=\alpha+\beta 1 \mathrm{X} 1+\beta 2 \mathrm{X} 2+\beta 2 \mathrm{X} 2+\beta 3 \mathrm{X} 3+\varepsilon$

(1)

Keterangan:

$\mathrm{Y} \quad=$ Computer Self Efficiacy

$\alpha \quad=$ Konstanta

$\beta 1-\beta 3=$ Koefisien Regresi

$\mathrm{X} 1=$ Perceived Easy Of Use

$\mathrm{X}_{2}=$ Perceived Usefulness

$\mathrm{X} 3=$ Actual Usage

$\varepsilon=$ Faktor lain yang berpengaruh terhadap variabel terikat $(\mathrm{Y})$

Hasil uji regresi linear berganda dapat dilihat pada Tabel 1 Pengujian tersebut dilakukan terhadap variabel perceived easy of used, perceived usefulness dan actual usage pada computer self efficiacy.

Tabel 1

Hasil CijRereresi Limear Berganda

\begin{tabular}{|c|c|c|c|c|c|}
\hline \multirow[b]{2}{*}{. $.0 d e l$} & \multicolumn{2}{|c|}{$\begin{array}{l}\text { Unstandardized } \\
\text { Coefficicients }\end{array}$} & $\begin{array}{l}\text { Standardized } \\
\text { Coefficicents }\end{array}$ & \multirow[b]{3}{*}{$t$} & \multirow[b]{3}{*}{ Sig, } \\
\hline & & Std. & & & \\
\hline No Variabel & B & Error & Beta & & \\
\hline $1 \overline{C o m p u t e r ~ S e f ~ E f f i c i a c y ~(Y) ~}$ & $-0,938$ & 0,816 & & $-1,150$ & 0,252 \\
\hline 2 Perceived Easy Of Use (XI) & 0,236 & 0,039 & 0,3 & 6,116 & 0,000 \\
\hline 3 Percened Useffiness (X2) & 0,270 & 0,039 & 0,3 & 7,000 & 0,000 \\
\hline 4 Actual Usage $(X 3)$ & 0,215 & 0,031 & 0,3 & 6,960 & 0,000 \\
\hline Konstanta & & & 0,914 & & \\
\hline $\mathrm{Sig} \mathrm{F}$ & & & 0,000 & & \\
\hline Adjusted R Square & & & 0,912 & & \\
\hline
\end{tabular}

Sumber: Data diolah (2019)
Berdasarkan hasil analisis regresi linear berganda yang ditunjukan pada Tabel 1, maka dapat dibuat persamaan regresi sebagai berikut:

\section{$\mathrm{Y}=0,914+0,313 \mathrm{X} 1+0,355 \mathrm{X} 2+$ $0,354 X 3+\varepsilon(1)$}

Koefisien persamaan regresi di atas mengindikasikan bahwa variabel perceived easy of use, perceived usefulness dan actual usage memiliki pengaruh searah dengan variabel terikat yaitu computer self efficiacy. Selain itu, hasil regresi juga menunjukkan Adjusted $R$ Square sebesar 0,912. Hal tersebut menunjukkan bahwa variabilitas variabel computer self efficiacy dapat dijelaskan oleh variabel perceived easy of use, perceived usefulness dan actual usage sebesar $91,2 \%$ persen, sedangkan sisanya sebesar 8,8 persen dijelaskan oleh variabel-variabel lain di luar model penelitian.

Nilai koefisien regresi variabel perceived easy of use (X1) sebesar 0,313, , perceived usefulness (X2) sebesar 0,355, dan actual usage (X3) sebesar 0,354, Hasil tersebut menunjukkan bahwa variabel perceived easy of use, perceived usefulness dan actual usage berpengaruh positif pada computer self efficiacy pengguna Sistem Informasi Akuntansi di PT Bank Rakyat Indonesia, cabang Gianyar.

\section{Uji Statistik F}

Hasil uji $F$ atau uji kelayakan model pada Tabel 1 menunjukkan pengaruh seluruh variabel bebas terhadap variabel terikat. Uji ini dilakukan sebelum melakukan pengujian 
terhadap hipotesis. Apabila uji F menunjukkan hasil yang signifikan, maka seluruh variabel bebas mempengaruhi variabel terikat dan model yang digunakan layak uji, sehingga pengujian hipotesis dapat dilanjutkan.

Tingkat probabilitas (sig.) $\mathrm{F}$ adalah $0,000 \leq \alpha=0,05 ; \mathrm{H} 1$ diterima dan $\mathrm{H}_{0}$ ditolak, Hasil penelitian menunjukkan nilai signifikasi F sebesar 0,000 lebih kecil dari $\alpha=0,05$, sehingga dapat disimpulkan bahwa variable perceived easy of use, perceived usefulness dan actual usage secara bersama memprediksi dan menjelaskan computer self efficiacy pengguna Sistem Informasi Akuntansi di PT Bank Rakyat Indonesia, cabang Gianyar.

\section{Uji Statistik t}

Hasil uji $\mathrm{t}$ pada
$\begin{aligned} & \text { Tabel } 1 \\ & \text { menunjukkan } \\ & \text { pengaruh }\end{aligned}$
perceived easy of use, perceived usefulness dan actual usage pada computer self efficiacy pengguna Sistem Informasi Akuntansi di PT Bank Rakyat Indonesia, cabang Gianyar secara parsial. Pengujian masing-masing variabel bebas pada variabel terikat dijelaskan sebagai berikut.

\section{Pengaruh Perceived Easy of Use pada}

\section{Keyakinan Diri Atas Komputer}

\section{Pengguna Sistem Informasi Akuntansi}

Hipotesis pertama $\left(\mathrm{H}_{1}\right)$ menyatakan bahwa perceived easy of use berpengaruh positif pada keyakinan diri atas komputer pengguna Sistem Informasi Akuntansi di PT Bank Rakyat Indonesia, Tbk. Cabang Gianyar. Pengujian terhadap pengaruh perceived easy of use pada keyakinan diri atas komputer dilakukan dengan melihat hasil uji statistik t. Tingkat probabilitas (sig.) t variabel pengalaman adalah $0,000<\alpha=$ 0,05. Hal ini menunjukkan bahwa $\mathrm{H}_{1}$ diterima dan $\mathrm{H}_{0}$ ditolak.

Perkembangan Teknologi Informasi saat ini sangat cepat, baik perkembangan Teknologi Informasi dari segi hardware maupun softwarenya. Dalam satu sisi perkembangan itu sangat membantu bagi novice accountant (usernya), sementara di sisi lain ada sebagian user yang merasa cemas (anxiety), takut (affried) dan tidak mampu untuk mengikuti perkembangan tersebut atau bahkan menolak perkembangan tersebut. Hasil penelitian Darsono (2005) menunjukkan bahwa keyakinan-diri atas komputer berpengaruh terhadap persepsi kemudahan penggunaan dan terhadap minat menggunakan internet. Karyawan pada PT Bank Rakyat Indonesia, Tbk. Cabang Gianyar menganggap jika semakin mudah suatu Sistem Informasi Akuntansi diterapkan saat menyelesaikan pekerjaan, maka keyakinan karyawan untuk menggunakan komputer akan semakin tinggi. Temuan ini konsisten dengan temuan Hong, et al. (2002), Lewis et al (2003), dan didukung oleh Hassan (2006) yang menemukan bahwa perspsi kemudahan berpengaruh positif terhadap keyakinan diri atas computer. Penelitian Thompson et al (2006), Hassan (2007) dan Srite et al (2008) juga menemukan bahwa persepsi kemudahan pengguna berpengaruh positif terhadap keyakinan diri atas komputer. 
Pengaruh Perceived Usefulness pada Keyakinan Diri Atas Komputer Pengguna Sistem Informasi Akuntansi

Hipotesis kedua $\left(\mathrm{H}_{2}\right)$ menyatakan bahwa perceived usefulness berpengaruh positif pada keyakinan diri atas komputer pengguna Sistem Informasi Akuntansi di PT Bank Rakyat Indonesia, Tbk. Cabang Gianyar. Pengujian terhadap pengaruh perceived usefulness pada keyakinan diri atas komputer dilakukan dengan melihat hasil uji statistik t. Tingkat probabilitas (sig.) $\mathrm{t}$ variabel pengalaman adalah $0,000<\alpha=$ 0,05. Hal ini menunjukkan bahwa $\mathrm{H}_{2}$ diterima dan $\mathrm{H}_{0}$ ditolak.

Davis et al. (1989) menemukan bahwa perceived usefulness mempunyai hubungan yang lebih kuat dan konsisten dengan penerimaan teknologi informasi dibandingkan dengan variabel lain, seperti sikap, kepuasan, dan ukuran-ukuran persepsian yang lain. Hasil penelitian yang dilakukan oleh Igbaria (1990) dan Robey et al. (1989) juga menemukan hal yang sama, yaitu adanya hubungan positif antara perceived usefulness dengan penggunaan sistem informasi. Karyawan di PT Bank Rakyat Indonesia, Tbk. Cabang Gianyar menganggap adanya Sistem Informasi Akuntansi sangat membantu dalam menyelesaikan pekerjaannya. Dengan adanya Sistem Informasi Akuntansi karyawan dapat lebih cepat dalam menyelesaikan pekerjaan, memudahkan pelayanan terhadap nasabah, dan dapat menjadikan sebuah informasi lebih efektif dan efisien. Adam et al. (1992) melakukan telaah terhadap dua hasil penelitian yang mereplikasi penelitian Davis (1989). Hasilnya adalah satu penelitian menunjukkan bahwa perceived usefulness juga merupakan faktor penentu utama penggunaan sistem komputer.

\section{Pengaruh Actual Usage pada Keyakinan}

Diri Atas Komputer Pengguna Sistem

\section{Informasi Akuntansi}

Hipotesis ketiga $\left(\mathrm{H}_{3}\right)$ menyatakan bahwa actual usage berpengaruh positif pada keyakinan diri atas komputer pengguna Sistem Informasi Akuntansi di PT Bank Rakyat Indonesia, Tbk. Cabang Gianyar. Pengujian terhadap pengaruh actual usage pada keyakinan diri atas komputer dilakukan dengan melihat hasil uji statistik t. Tingkat probabilitas (sig.) $\mathrm{t}$ variabel pengalaman adalah $0,000<\alpha=$ 0,05. Hal ini menunjukkan bahwa $\mathrm{H}_{3}$ diterima dan $\mathrm{H}_{0}$ ditolak.

Penelitian mengenai pengaruh tingkat penerimaan dilakukan oleh Wijaya (2005) dalam penelitiannya mengenai pengaruh faktor demografi dan personality terhadap keahlian dalam End User Computing menyatakan bahwa karyawan yang lebih tua mempunyai lebih sedikit pengetahuan dan pelatihan komputer dibanding dengan karyawan yang lebih muda. Oleh karena itu mereka mempunyai sikap yang kurang baik terhadap mikro komputer. Syam (1999) dalam penelitiannya menyatakan bahwa aspek perilaku dan kemampuan pengaplikasian Sistem Informasi Akuntansi menjadi faktor penentu bagi kompleksitas Sistem Informasi Akuntansi tersebut. Semakin konstruktif perilaku dan semakin tinggi keahlian pengguna Sistem Informasi Akuntansi akan menyebabkan kompleksitas Sistem Informasi Akuntansi berdampak positif bagi strategi dan 
kelangsungan bisnis perusahaan. Penggunaan Sistem Informasi Akuntansi di PT Bank Rakyat Indonesia, Tbk. Cabang Gianyar diimplementasikan dengan baik, dengan adanya pembaharuan sistem secara berkala yang diberlakukan oleh PT Bank Rakyat Indonesia, Tbk. pengguna Sistem Informasi Akuntansi harus dapat mempelajari dan mengimplementasikan penggunaan sistem, sehingga dengan adanya pengetahuan tentang penggunaan sistem maka karyawan yakin dalam menggunakan Sistem Informasi Akuntansi yang diberlakukan. Selanjutnya Wijaya (2005) dengan hasil penelitian menunjukkan bahwa teknologi dapat diterima dengan baik oleh penggunanya karena dirasakan memberikan kemudahan dan kegunaan dalam membantu penggunanya dalam mencari informasi yang dibutuhkan.

\section{KESIMPULAN DAN SARAN}

a. $\mathrm{H}_{1}$ diterima dan $\mathrm{H}_{0}$ ditolak

b. $\mathrm{H}_{2}$ diterima dan $\mathrm{H}_{0}$ ditolak c. $\mathrm{H}_{3}$ diterima dan $\mathrm{H}_{0}$ ditolak

\section{DAFTAR PUSTAKA}

Davis, F.D. 1989. Perceived Usefulness, Perceived Ease of Use dan Acceptance of Information System Technology. MIS Quartery, Vol. 13, No. 3, h.319-339.

Ghozali, I. 2004. Model Persamaan Struktural: Konsep dan Aplikasi dengan Program AMOS Ver. 5.0. Semarang : BP Universitas Diponegoro.

Igbaria, M., Saroj Parasuraman., dan Michael K. Badaway. 1994. Work Experience, Job Involvement, and Quality of Work Life Among Information Systems Personnel. MIS Quarterly, Juni, h.175-201.

Venkatesh, V dan F.D. Davis. 1996. “ A Model of The Antecendents of Perceived Ease of Use = Develompment dan Test", Decision Science Vol. 27, , h.451- 481. 